\title{
Pregnancy outcomes in women affected by juvenile idiopathic arthritis (JIA)
}

\author{
Maria Giannina Alpigiani, Pietro Salvati, Serena Callegari, Renata Lorini \\ From 21st European Pediatric Rheumatology (PReS) Congress \\ Belgrade, Serbia. 17-21 September 2014
}

\section{Introduction}

JIA is the most frequent form of persistent arthritis in children that begins at or before 16 years old. While outcome of pregnant women with RA is well-known, at best of our knowledge there are a few scientific works about pregnancy in JIA patients $[1,2]$.

\section{Objectives}

Our aim is to describe pregnancy outcomes in a case series of six women affected by JIA.

\section{Methods}

We report on six cases of women affected by JIA with a median age of 32,8; median age at onset of 6,1; median age at first delivery of 25,7. (table 1)

\section{Results}

In all cases, pregnancy was associated with remission of disease activity, however a post partum flare appeared after 4 pregnancies ( pt 1-4-5-6) and in the first year postpartum. The seven babies were in good condition, without

\begin{tabular}{|c|c|c|c|c|c|c|c|}
\hline & $\begin{array}{l}\text { Age }(y, \\
\mathrm{m})\end{array}$ & $\begin{array}{l}\text { Age at } \\
\text { onset }\end{array}$ & Type & $\begin{array}{c}\text { Therapy before } \\
\text { pregnancy }\end{array}$ & $\begin{array}{l}\text { Age at delivery }[\mathrm{pS} 1] \text { (y } \\
\mathbf{m})\end{array}$ & $\begin{array}{l}\text { Sex of } \\
\text { babies }\end{array}$ & $\begin{array}{c}\text { Flare after } \\
\text { delivery }\end{array}$ \\
\hline $\begin{array}{c}\text { Patient } \\
1 \\
\text { LS }\end{array}$ & $297 / 12$ & 12 y $2 / 12$ & poliarticular & None & $\begin{array}{c}1811 / 12 \\
247 / 12\end{array}$ & $0^{\prime \prime} \sigma^{x}$ & yes \\
\hline $\begin{array}{c}\text { Patient } \\
2 \\
\text { GM }\end{array}$ & $387 / 12$ & $8 y$ & poliarticular & none & $273 / 12$ & ㅇ & no \\
\hline $\begin{array}{c}\text { Patient } \\
3 \\
\text { GA }\end{array}$ & $2911 / 12$ & $4 y$ & oligoarticular & none & $259 / 12$ & $0^{n}$ & no \\
\hline $\begin{array}{c}\text { Patient } \\
4 \\
\text { CE }\end{array}$ & $3711 / 12$ & 1 y $4 / 12$ & poliarticular & none & $269 / 12$ & Q & yes \\
\hline $\begin{array}{c}\text { Patient } \\
5 \\
\text { RL }\end{array}$ & $345 / 12$ & 8 y $7 / 12$ & poliarticular & Cya, steroids & $293 / 12$ & ㅇ & yes \\
\hline $\begin{array}{c}\text { Patient } \\
6 \\
\text { BA }\end{array}$ & 26 10/12 & 2 y $8 / 12$ & poliarticular & none & $262 / 12$ & $0^{x}$ & yes \\
\hline
\end{tabular}

Pediatrics, Istituto G. Gaslini, Genova, Italy

(c) 2014 Alpigiani et al; licensee BioMed Central Ltd. This is an Open Access article distributed under the terms of the Creative B. Wed Central Commons Attribution License (http://creativecommons.org/licenses/by/4.0), which permits unrestricted use, distribution, and (http://creativecommons.org/publicdomain/zero/1.0/) applies to the data made available in this article, unless otherwise stated. 
apparent malformation or symptoms of neonatal illness. Only 1 woman was treated during her pregnancy: the number 5 patient received oral cyclosporine for the first 5 months of pregnancy and oral low-dose corticosteroids for all pregnancy; she had an active disease before pregnancy and she had an important flare a few months after delivery.

As reported for pregnant patients affected by RA (Dolhain RJEM 2010), in our cases pregnancy was associated with a remission of disease in $6 / 6$ patients and flare in post-partum period in $4 / 6$ patients, probably depending on increased levels of serum alfa 2 glycoprotein and elevated levels of sex hormones that influence a shift in cytokine production from a Th1 to a Th2 profile. In fact, oestrogens inhibit $\mathrm{T}$-cell function, progesterone stimulates Th2 effects and cortisol has a general immunosuppressive effect.

The number 5 patient was treated with cyclosporine and steroids. No congenital anomalies or increase of death rate were observed in infants exposed to cyclosporine antenatally. Besides low-dose steroids therapy (5-15 mg prednisone daily) does not increase low-birth-weight or small for gestation age infants.

\section{Conclusion}

In conclusion, in JIA patients, a stable disease or remission should be reached before pregnancy and should be used safe immunosuppressive drugs to avoid a flare during pregnancy and in post-partum period.

\section{Disclosure of interest}

None declared.

Published: 17 September 2014

\section{References}

1. Chakravarty EF: 2003

2. Chen JS: 2013 .

doi:10.1186/1546-0096-12-S1-P206

Cite this article as: Alpigiani et al:. Pregnancy outcomes in women

affected by juvenile idiopathic arthritis (JIA). Pediatric Rheumatology 2014 12(Suppl 1):P206.
Submit your next manuscript to BioMed Central and take full advantage of:

- Convenient online submission

- Thorough peer review

- No space constraints or color figure charges

- Immediate publication on acceptance

- Inclusion in PubMed, CAS, Scopus and Google Scholar

- Research which is freely available for redistribution

Submit your manuscript at www.biomedcentral.com/submit 